\title{
Lipid Fluidity as an Essential Therapeutic Tool for Cell Pathology
}

\section{Sinerik Ayrapetyan*}

Life Sciences International Postgraduate Educational Center, Yerevan 0040, Armenia

\section{Editorial}

It is known that the decrease of $\mathrm{Na}^{+}$gradients on cell membrane is a common consequence of cell pathology. According to the classical membrane theory, low permeability of cell membrane for $\mathrm{Na}^{+}$and high permeability for $\mathrm{K}^{+}$are the main reasons for asymmetric distribution of inorganic ions between intra- and extra-cellular mediums and generation of Membrane Potential (MP) [1]. However, this theory is unable to explain the mechanism of the metabolic control of semi-permeable properties of cell membrane for inorganic ions, which are disturbed in cell pathology. Our previous work, performed on squid axons and snail neurons, has shown that water efflux from the cells has inactivation effect on inward $\mathrm{Na}^{+}$and $\mathrm{Ca}^{2+}$ currents and activation effect on outward $\mathrm{K}^{+}$currents, while the water uptake has opposite effect on them [2].

The facts that intracellular osmotic pressure exceeds the extracellular one and cell membrane permeability for water is much higher (more than ten times) than for ions $[3,4]$, allow us to assume that intracellular metabolism should generate water efflux from the cell in order to balance the osmotic uptake of water by cells. Therefore, we have suggested that metabolically generated water efflux from the cells is the main mechanism through which the metabolic control of membrane permeability for inorganic ions is realized [5].

The metabolically generated water efflux from the cell takes place by two mechanisms: a) Ion transporting system which pushes out more osmotic active particles from the cells than uptakes it; and b) Intracellular oxidative processes leading to the release of water molecules in cytoplasm (one molecule glucose oxidation generates $42 \mathrm{H}_{2} \mathrm{O}$ ).

Among the metabolic mechanisms generating water efflux from the cell, $\mathrm{Na}^{+} / \mathrm{K}^{+}$pump has a crucial role. On one side, $\mathrm{Na}^{+} / \mathrm{K}^{+}$pump decreases intracellular osmolarity due to its $3 \mathrm{Na}^{+}: 2 \mathrm{~K}^{+}$stoichiometry, on the other side it stimulates the release of $\mathrm{H}_{2} \mathrm{O}$ in cytoplasm as a result of activation of intracellular phosphorylation processes.

Osmotic water uptake by cells takes place through: a) Membrane lipids; b) Water aqua pores [3]; and c) Ionic channels [2,6].

Water efflux through lipid phases of the membrane depends on lipid fluidity. The latter is increased by cell swelling, heating, involvement of unsaturated fatty acids in lipids as well as by the factors having elevation effect on both intracellular $\mathrm{Ca}^{2+}$-induced activation of lipase activity and $\beta$-oxidation of fatty acids $[7,8]$. As $\mathrm{Na}^{+} / \mathrm{K}^{+}$pump regulates all the mentioned cell parameters [9], the $\mathrm{Na}^{+} / \mathrm{K}^{+}$pump-induced membrane fluidity decrease serves as one of the pathways through which $\mathrm{Na}^{+}$/ $\mathrm{K}^{+}$pump counteracts osmotic water uptake by cells and decreases cell membrane permeability for $\mathrm{Na}^{+}$and $\mathrm{Ca}^{2+}$.

It is known that the activation of cell metabolism leads to formation of unsaturated fatty acids in membrane through the activation of $\beta$ oxidation of fatty acids, including fatty acids with short carbon chain (fewer than 10 carbon atoms). By our previous study it has been shown that the application of non-metabolized 2-decenoic acid (DA), which increases membrane fluidity by $40 \%$ [10], leads to neuronal swelling and blocks $\mathrm{Na}^{+}$channels due to the increase of water fluxes through the lipids, in this way weakening water uptake-induced activation effect on $\mathrm{Na}^{+}$channels [11]. It has also been shown that the elevation of membrane lipid fluidity by this mechanism brings to potential- independent inhibition of bursting activity (Epileptiform discharge) of neurons [10] and depresses synaptic transmitters-induced membrane activity and $\mathrm{Na}^{+} / \mathrm{Ca}^{2+}$ exchange in membrane. Therefore, based on the aforementioned data, it can be concluded that the increase of membrane fluidity could serve as a universal hallmark for cell pathology, including cancer, and the factors, which depress membrane fluidity, could have therapeutic effect and serve as a focal point for physiotherapeutic and chemotherapeutic treatments of different diseases $[12,13]$.

\section{References}

1. Hodgkin AL (1964) The conduction of the nervous impulse. Liverpool University Press.

2. Ayrapetyan SN, Rychkov GY, Suleymanyan MA (1988) Effects of water flow on transmembrane ionic currents in neurons of Helix Pomatia and in squid giant axon. Comp Biochem Physiol 89: 179-186.

3. Borgnia M, Nielsen S, Engel A, Agre P (1999) Cellular and molecular biology of the aquaporin water channels. Annu Rev Biochem 68: 425-458.

4. Hoffmann EK, Sørensen BH, Sauter DP, Lambert IH (2015) Role of volumeregulated and calcium-activated anion channels in cell volume homeostasis, cancer and drug resistance. Channels (Austin) 9: 380-396.

5. Ayrapetyan S (2016) Cell hydration-induced changes of membrane conductivity as a marker for estimation of biological effects of chemical and physical factors on organism. J Bioequiv Availab 8: 4

6. Rychkov GY, Suleymanyan MA, Ayrapetyan SN (1989) Dependence of water flow effect on the ionic currents of dialyzed neuron of somatic membrane fluidity. Biol Membr 6: 733-739.

7. Beloribi-Djefaflia S, Vasseur S, Guillaumond F (2016) Lipid metabolic reprogramming in cancer cells. Oncogenesis 5: 49 .

8. Noutsi P, Gratton E, Chaieb S (2016) Assessment of membrane fluidity fluctuations during cellular development reveals time and cell type specificity.

9. Ayrapetyan $\mathrm{S}(2017)$ Reverse mode $\mathrm{Na}^{+} / \mathrm{Ca}^{2+}$ exchange-induced cell dehydration as a primary mechanism for cell pathology. Glob Drugs Ther 2: 1-4.

10. Ayrapetyan SN, Bakunts IS, Saghyan AA, Takenaka T, Dadalian SS (1986) Membrane fluidity as a factor modulating the counter-gradient transport of sodium ions from the cell. Dokl Akad Nauk SSSR 291: 469-472.

11. Suleymanian MA, Takenaka T, Stamboltsyan KV, Ayrapetyan SN (1986) The effects of short-chain fatty acids on the neuronal membrane functions of Helix Pomatia. I electrical properties. Cell Mol Neurobiol 6: 151-163.

12. Arvanov VL, Takenaka T, Dadalian SS, Ayrapetyan SN (1986) The effects of short-chain fatty acids on the neuronal membrane functions of Helix Pomatia. II. Cholinoreceptive properties. Cell Mol Neurobiol 6: 165-175

13. Saghyan AA, Dadalian SS, Takenaka T, Suleymanian MA, Ayrapetyan SN (1986) The effects of short-chain fatty acids on the neuronal membrane functions of Helix pomatia. III 22Na Efflux from the cell. Cell Mol Neurobiol 6: 397-405.

${ }^{*}$ Corresponding author: Sinerik Ayrapetyan, Life Sciences International Postgraduate Educational Center, UNESCO Chair in Life Sciences, Acharyan 31, Yerevan 0040, Armenia, Tel: +374 10 624170/612461; Fax: +374 10624170 E-mail: info@biophys.am

Received August 16, 2017; Accepted August 17, 2017; Published August 24, 2017

Citation: Ayrapetyan S (2017) Lipid Fluidity as an Essential Therapeutic Tool for Cell Pathology. J Bioequiv Availab 9: e80. doi: 10.4172/jbb.10000e80

Copyright: $\odot 2017$ Ayrapetyan S. This is an open-access article distributed unde the terms of the Creative Commons Attribution License, which permits unrestricted use, distribution, and reproduction in any medium, provided the original author and source are credited. 